\title{
The epistolary archive of Raffaele Bendandi, a seismologist standing outside the institutions
}

\author{
Paola Lagorio \\ Associazione culturale «La Bendandiana», Faenza, Italy
}

\begin{abstract}
Raffaele Bendandi (1893-1979) is a typical, very Italian, of a scholar of s example eismology, trained outside the institutions and with whom relations were difficult for most of the time. A skilled craftsman, endowed with great inquisitiveness and undoubted intelligence and endeavour, Bendandi was self-taught and his seismological and astronomical interests merged in his theory of planetary influence in the process of release of seismic energy. The practical result of this theory was the possibility, according to Bendandi, of foreseeing earthquakes in every part of the world. From the 1920s until his death, Bendandi made numerous forecasts for different parts of the world arousing the interest of people and countless national and international newspapers. The Bendandi phenomenon ended up being considered a problem for official science and for some governments, which forbade the dissemination of his forecasts. Bendandi's human and scientific story is documented in what remains of his archive of handwritten studies: letters, daily notes with his forecasts. All of this material is being reordered, digitally scanned and studied at Casa Bendandi, the head quarters of «La Bendandiana» association of Faenza, and will be made available to the scientific community and the history of science.
\end{abstract}

Key words scientific letters - earth sciences seismology

\section{A short biography}

Raffaele Bendandi was born in Faenza on 17 th October 1893 to a modest family of workers: their scarce financial resources did not allow him to pursue his education and so he only went to primary school.

He worked at the workshop of a watchmaker and at an engraver's. The manual experience acquired and an innate artistic sense subsequently helped him to make precision instruments and drawings and graphs supporting his theories.

Mailing address: Dr. Paola Lagorio, Associazione culturale «La Bendandiana», Via Manara 17, 48018 Faenza (RA), Italy.
«[...] the end of 1917 saw me by chance mobilised at one of the many squadrons of seaplanes disseminated in a war zone. The period was one of the most critical; but although the war operations did not grant us a reprieve, in the brief moments of rest between the reiterated reconnaissance flights that we were allowed, I was fond of taking solitary leave to contemplate nature and its grandiose manifestations and ponder on its deep teachings [...]» (Archivio Bendandi, Il caso non esiste, 1955).

It is from this meditation, from this discovery of wave motion, the lunisolar attraction, that Bendandi developed his motivation for careful, scrupulous and methodical study of the natural phenomena in general and earthquakes in particular.

Probably in the emotional wake of the Marsina earthquake on 13th January 1915, in the same year Bendandi set up one of the first Osservatorio geofisico, equipping it with the seismographs he had designed. Instruments that he subsequently perfected until he had them 


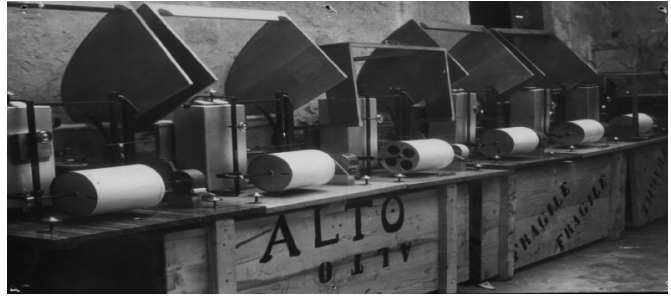

Fig. 1. «RABEN» (RAffaele BENdandi) micro seismographs, lined up at the Observatory and ready for shipping.

mass produced by the Bolognese manufacturer «Pirotti M. e Figlio, exclusive licensee for Italy and Europe» (fig. 1).

Bendandi's interests were multiple and all pursued with dedication and accuracy; in the period between 1920 and 1940 much of his energy was focused on the study of earthquakes and their forecasting, but the academic world never accepted his hypotheses (not corroborated by concrete elements) and feeling vanquished in the effort to demonstrate his arguments, he closed himself in a mute silence.

\section{Raffaele Bendandi's epistolary archive}

In his museum-home in Via Manara, Faen$\mathrm{za}$, the recovery, digital reproduction and study of the epistolary archive is currently in progress (fig. 2), which to some extent mirrors the Faenza seismologist's life.

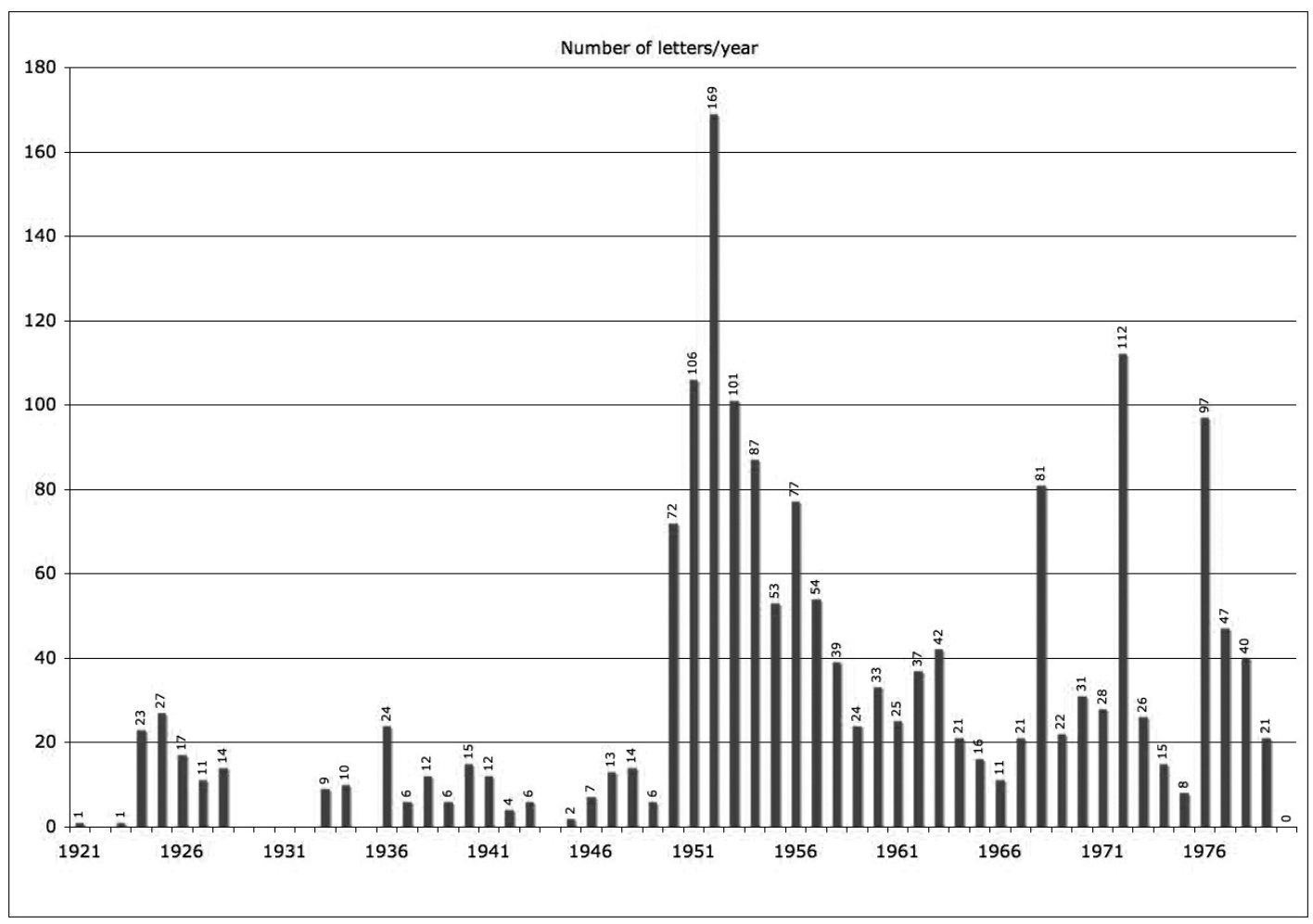

Fig. 2. Graphic summary of the decade-long distribution of the letters received by Bendandi and preserved in the «La Bendandiana» epistolary archive. The distribution of the number of letters per years discloses three periods: 1921-1949, with a modest epistolary activity documented; 1950-1958, with the peak in Bendandi's epistolary activity and an average of 84 letters per year; 1959-1979: the same number of letters as the previous period but with a decidedly lower average: 36 letters per year. 


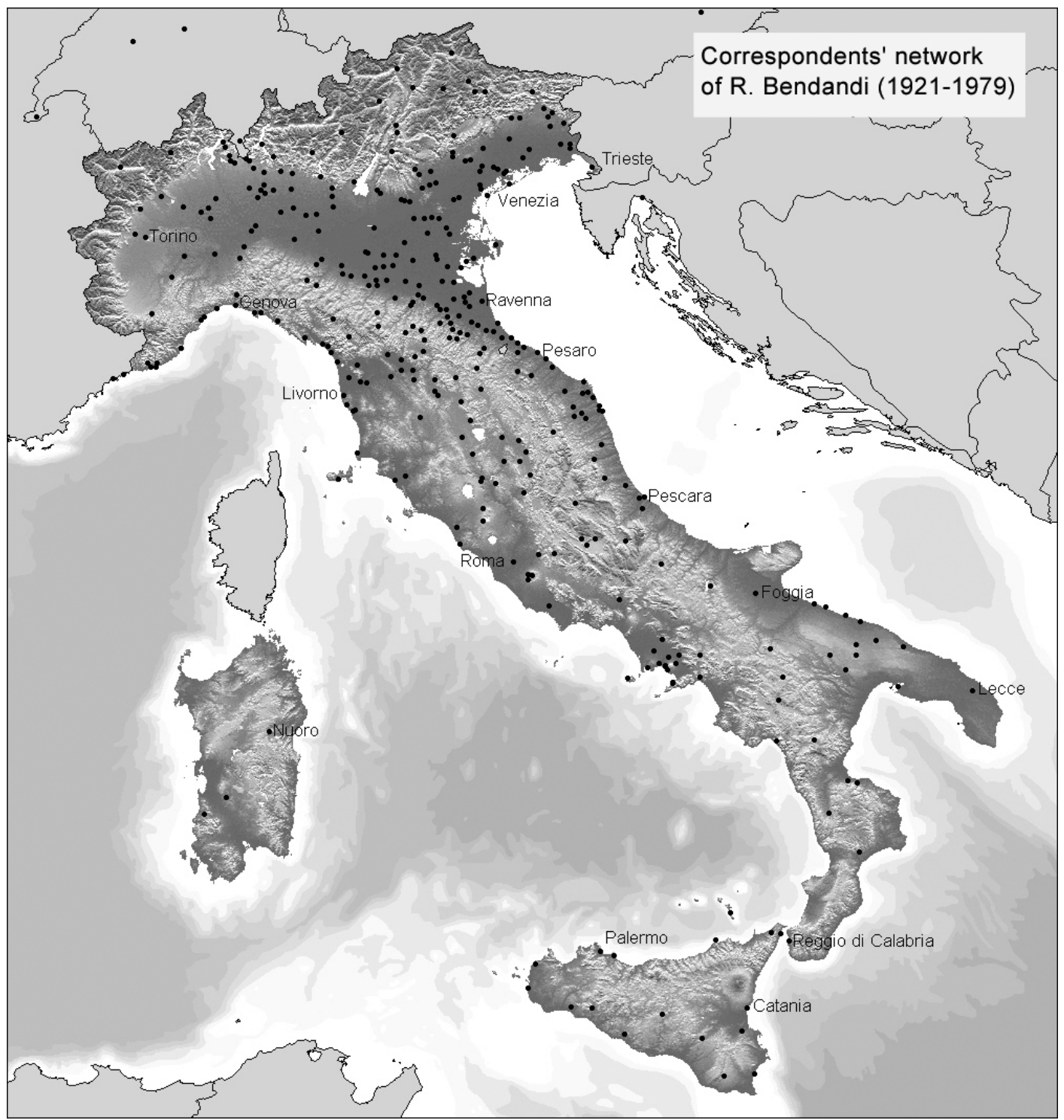

Fig. 3. Geographical localisation of the senders in Italy of letters to Bendandi.

The years from 1920 to 1979 constituted the fertile period of Bendandi's work: the letters received are dated from 1921, when the seismologist from Faenza started to take the stage, and ended in 1979 (the last one is dated 14th Octo- ber), the year of the scholar's death. It is not certain whether the letter archive is complete, for various reasons, amongst which the natural dispersion over long periods of time and in that the archive was taken over by the Municipality 


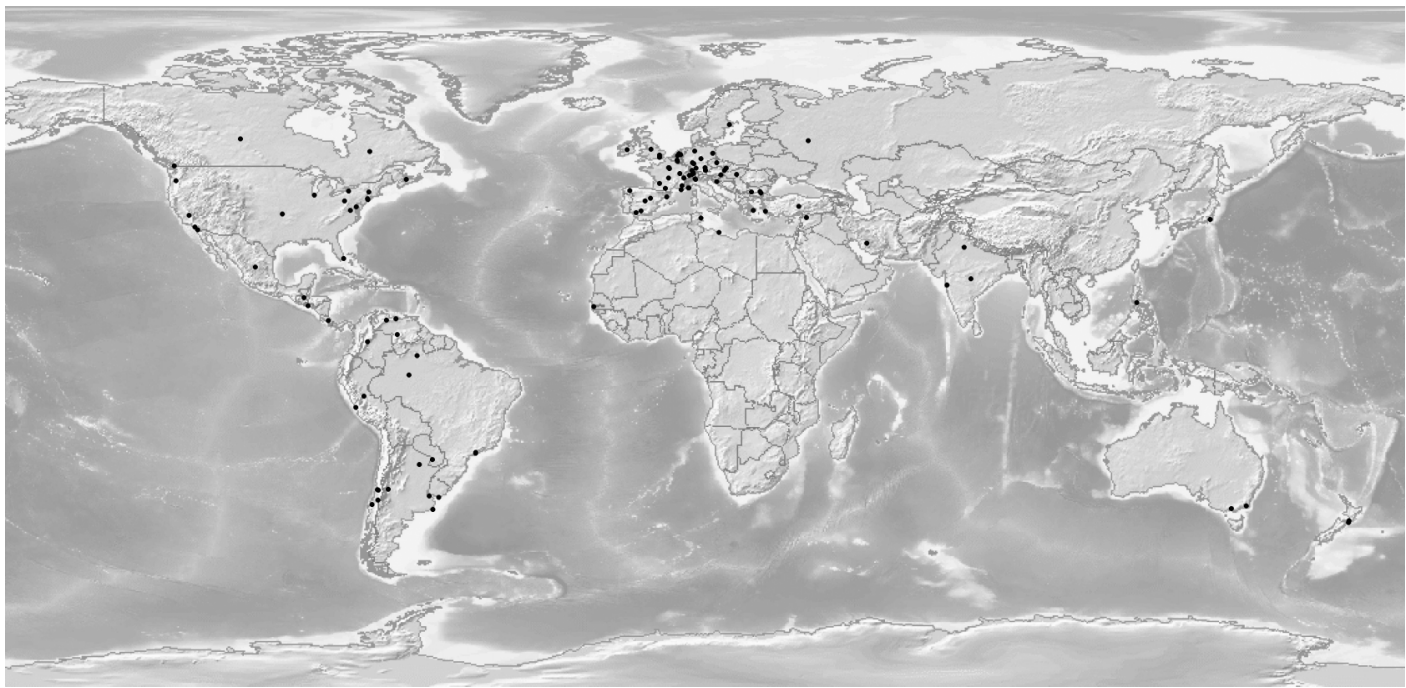

Fig. 4. Geographical localisation of the senders from abroad of letters to Bendandi.

only for a certain time after the scholar's death and the archive was visited by others.

The yearly scan of the graphic summary of fig. 2 can be divided into three periods in which the archive contains:

- 1921-1949: 240 letters, with an average per year of about 11 letters if we exclude the 6 years in which there is no epistolary activity recorded, in 1944 no mail was delivered to Bendandi, owing to the war;

- 1950-1958: 758 letters with a maximum of 169 letters in 1952 and other peaks in 1951 with 106 letters and in 1953 with 101;

- 1959-1979: 758 letters, with peaks of 81 in 1968 and 97 in 1976, and a maximum of 112 in 1972.

On examination of the letters coming from abroad, our attention shifts towards the first period - the 1920s - and then returns towards the 1950s: in greater detail, 1925 with 13 letters, 1926 again with 13, and 1928 with 11,1951 with 21, 1952 with16 and 1969 with seven. There were fa ew years when no letters arrived from abroad, three letters arrived even in the scholar's last year of life.

Careful scrutiny of the origin of the 1,756 letters constituting the epistolary archive under examination shows that most of them come from every part of Italy (fig. 3).

Likewise, we proceeded to examine the letters Bendandi received from every part of $\mathrm{Eu}-$ rope and from other continents: these are about 170 , nearly ten per cent of the epistolary archive.

Fig. 4 shows that in Europe the most represented countries were Germany and France, in the rest of the world the United States and South America, where Bendandi was particularly successful among the communities of Italian emigrants.

The epistolary archive comprises letters of various types with regard to the contents, written by highly heterogeneous senders, amongst whom:

- Scholars who exchanged earthquake data with him (fig. 5);

- Young students of different ages (scholastic and non-scholastic) who asked him for information and explanations concerning some aspects of physics, in regard to earthquakes and his forecasting theory;

- People offering their assistance, economic and non-economic, and their skills to collaborate with Bendandi in his multifarious activities (fig. 6); 


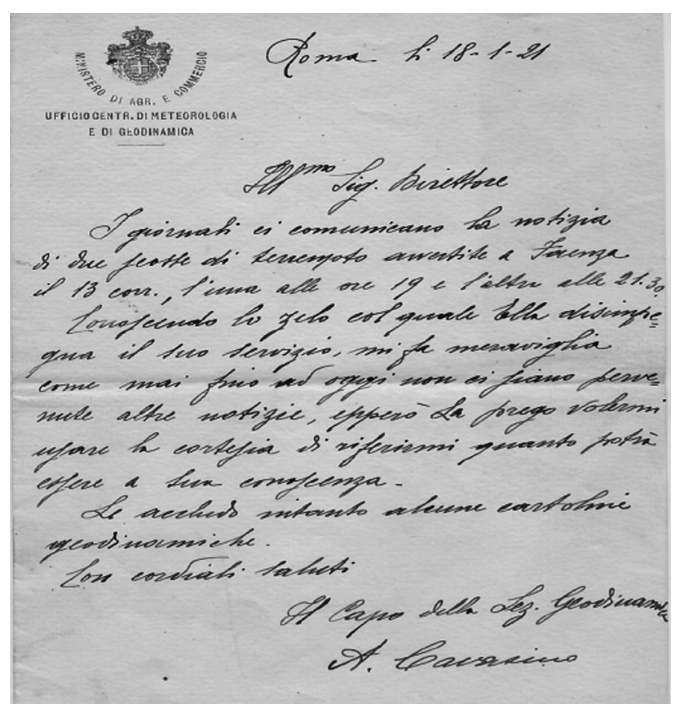

Fig. 5. Letter dated 18th January 1921 in which Alfonso Cavasino, head of the geodynamic section of the Central Office of Meteorology and Geodynamics asks Bendandi for information about the earthquake recorded in Faenza on 13th January (the first shock was at around $19.00 \mathrm{hrs}$ and the other at $21.30 \mathrm{hrs}$ ).

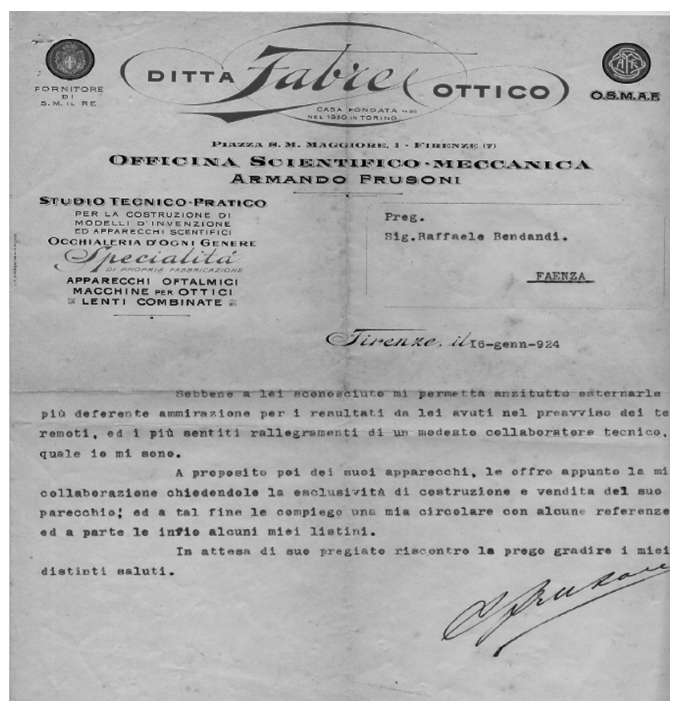

Fig. 6. Letter of Armando Frusoni, proprietor of the Officina Scientifico-Meccanica Frugoni, who offers Bendandi his collaboration, asking for the exclusivity for the manufacture and sale of his device.

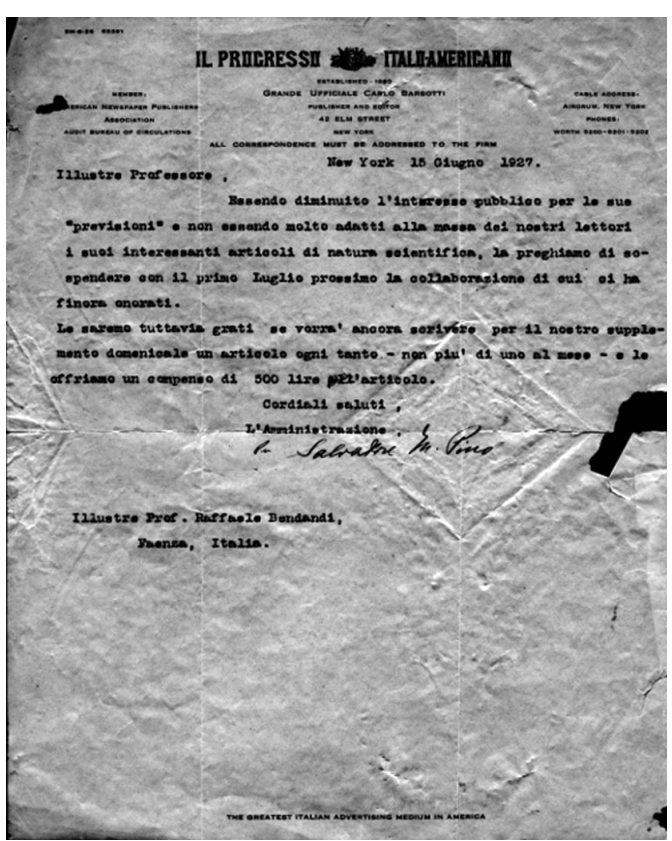

Fig. 7. Salvatore Pino director of the newspaper $I l$ Progresso Italo-Americano of New York asks «the illustrious Professor to suspend from the 1st July the collaboration that he has hitherto honoured us with», as the public's interest in his forecasts had diminished.

The articles of a scientific nature written by Bendandi are addressed to an over-limited circle of readers, so he is offered a periodic and no longer systematic collaboration, with a fee of 500 lire per article.

- Journalists and correspondents (fig. 7);

- Ministerial officials;

- Correspondents of every social class who congratulated the scholar, after reading his articles published on journals with nationwide readership, asking for advice on the places to go and live to be «safer», showing blind faith in the forecasting skills of the seismologist hailing from Faenza (fig. 8);

- Bendandi's epistolary archive is an important nucleus for the documentation of human feeling faced with problems that are daunting in their complexity, tragic consequences and unpredictability.

The perusal of the letters turns out to be 


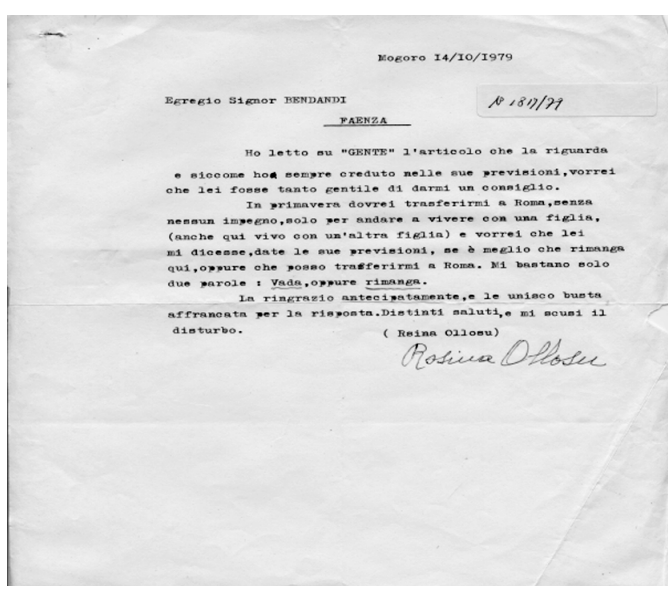

Fig. 8. The writer is a lady from Mogoro, in Sardinia; after reading an article in the magazine called Gente that reminded her of the seismologist and his forecasting capacities, renewing his esteem for him, she asked him for some advice on whether or not to move to Rome «I only need two words: Go or stay». This is the last letter received by Bendandi: the date is October 1979, around sixty years had passed since his first «efforts».

very interesting firstly because through these writings we manage to infer how well considered the scholar was both at national and international level. At times, this image contrasts with the one that so-called «official» science has of him, with which Bendandi only had a relationship based on collaboration in the early years of his activity, to be later kept at a safe distance when he was forbidden by the government to disseminate his forecasts.

In addition, from the letters we can trace further references that allow us to study and analyse the scholar's life and works.

The letters are mostly handwritten, with handwriting that is not instantly intelligible which makes interpretation quite hard.

For a proper preservation of the originals and for their more fruitful consultation, the material making up the epistolary collection has been digitally catalogued and reproduced. The contents have been summed up so as to show who was writing to Bendandi and with whom he was in epistolary contact and the consideration for his work and how this changed over time.

The first letters analysed belong to the period when Bendandi had just made public the fact that he possessed a theory capable of forecasting earthquakes: from these heterogeneous letters the admiration for the scholar transpires, the desire to get to know the method he was using, the hope that such a tremendous natural calamity could be «defeated».

Bendandi, given his character as a scholar outside the ranks of official seismology, had a complex and at times stormy relationship with the world of official science. From some letters, mostly in the early years, we can detect a habitual collaboration with the national bodies devoted to geodynamic studies (fig. 5), which progressively degenerated owing to the social repercussions of Bendandi's forecasts that were published by many newspapers.

The halo of mystery and trust that has surrounded the figure of Bendandi persisted until the last instant of his life: he died on 1st November 1979, in his Faenza home. This home was donated by the scholar to the Municipality of Faenza, which has made it into the headquarters of the institution named «La Bendandiana». It hosts his instruments and all of the documentation, which represents a point of reference for all the initiatives on the dissemination of geodynamic hazards and the contributions made by Bendandi to the scientific debate of his times.

\section{REFERENCES}

Archivio Bendandi, Il caso non esiste, 23 aprile 1955, unidentified newspaper cutting.

Archivio Bendandi, Fondo epistolare Bendandi, Lettera di Alfonso Cavasino da Roma a Raffaele Bendandi a Faenza, 18 gennaio 1921.

Archivio Bendandi, Fondo epistolare Bendandi, di Armando Frusoni da Firenze a Raffaele Bendandi a Faenza, 16 gennaio 1924.

Archivio Bendandi, Fondo epistolare Bendandi, Lettera di Salvatore Pino dell'amministrazione del Progresso Italo-Americano da New York a Raffaele Bendandi a Faenza, 15 giugno 1927.

Archivio Bendandi, Fondo epistolare Bendandi, Lettera di Rosina Ollosu da Mogoro a Raffaele Bendandi a Faen$z a, 14$ ottobre 1979. 